\title{
Identification of tumor-associated antigens in human hepatocellular carcinoma by autoantibodies
}

\author{
XIAOHONG CHEN ${ }^{1,2}$, SONGBIN FU $^{3}$, FENG CHEN $^{1}$, HUANYONG CHEN $^{2}$ and ZHI CHEN ${ }^{1}$ \\ ${ }^{1}$ Key Laboratory of Health Ministry, Institute of Infectious Diseases, The First Affiliated Hospital, School of Medicine, \\ Zhejiang University, Hangzhou; ${ }^{2}$ Department of Infectious Diseases, The First Clinical College of Haerbin \\ Medical University; ${ }^{3}$ Laboratory of Medical Genetics, Haerbin Medical University, Haerbin, P.R. China
}

Received April 22, 2008; Accepted May 26, 2008

DOI: $10.3892 /$ or_00000099

\begin{abstract}
Hepatocellular carcinoma (HCC) is a major cause of death in Asian countries. The false-negative rate with serum $\alpha$-fetaprotein level alone can reach $40 \%$ for early stage HCC patients. Due to the lack of sensitive and specific tumor markers for early diagnosis, it is impossible for HCC patients to receive effective therapy. However, tumor antigens can be recognized by immune cells and be rejected in immune responses. In order to identify antigens which may be used as new markers and immunotherapy targets for HCC, a cDNA expression library derived from an HCC sample was constructed, which was screened with mixed autologous and allogenic serum of HCC patients. Seventeen different HCC antigens were obtained, which are classified as tumorassociated antigens. A panel of allogenic sera from patients with chronic hepatitis, liver cirrhosis, HCC and other tumor entities and sera from health volunteers, was used for frequency analysis of antibody responses. Four of 17 antigens, including eukaryotic translation initiation factor 3, subunit I, lactate dehydrogenase 1, A chain, replication factor $\mathrm{C} 2,40 \mathrm{kDa}$ and mitochondrial carrier triple repeat 1 , reacted predominantly with sera from patients with $\operatorname{HCC}(31.8,45.5$, 27.3 and $50.0 \%$ respectively). Patients $(81.8 \%$ ) with HCC had the antibody against at least one of these four antigens, which indicates that disease-specific humoral response against these antigens was induced in HCC patients and the corresponding antibodies may be used as tumor markers for HCC.
\end{abstract}

\section{Introduction}

Hepatocellular carcinoma (HCC) is major cause of death in Asian countries and is a terminal complication of chronic inflammatory and fibrotic liver diseases (1). The false-negative

Correspondence to: Dr Zhi Chen, Key Laboratory of Health Ministry, Institute of Infectious Diseases, The First Affiliated Hospital, School of Medicine, Zhejiang University, 79 Qingchun Road, Hangzhou, Zhejiang, P.R. China

E-mail: chenzhi@zju.edu.cn

Key words: hepatocellular carcinoma, tumor marker, tumorassociated antigen, autoantibody rate with AFP level alone maybe as high as $40 \%$ for patients with early stage HCC. Due to the lack of sensitive and specific tumor markers for early diagnosis, it is impossible for HCC patients to accept an effective therapeutic modality. Presently, surgery still plays a major role in the treatment of HCC, particularly for small HCC (2).

However, tumor-specific antigens (TSAs) and tumorassociated antigens (TAAs) can be recognized by immune cells and be rejected in immune responses. So they may be detected as tumor markers and be used as potential targets for cancer immunotherapy.

Serological analysis of recombinant cDNA expression library (SEREX) is a convenient and effective method to identify tumor antigens (3), which does not require cultured tumor cell lines or tumor-specific cytotoxic T lymphocytes (CTLs), compared with CTLs methods (4). SEREX has been applied to many tumor types, such as melanoma $(5,6)$, esophageal squamous cell cancer (7-9) and prostate cancer (10). A large amount of tumor antigen genes, including HOM-MEL-40/SSX, NY-ESO-1 and MAGE were detected. Vaccine therapies with specific peptides of tumor antigens, have been used for the treatment of patients with various malignant tumors, such as MAGE, NY-ESO-1 and NY-BR-1. Specific $\mathrm{CD}^{+} \mathrm{T}$ cell response was observed in cancer patients (11-16) and the clinical trial treatment resulted in regression or growth suppression of tumors (17-19). Some were suggested to be potential targets in cancer and the corresponding targeted immunotherapy which represents a viable therapeutic strategy $(20,21)$.

A great number of tumor antigen genes have been found in HCC patients using the SEREX technique, such as tat binding protein-1 (TBP-1), ribosomal protein L30 (rpl30), p100, albumin and SEC63 (22-25) and specific CTL responses to hepatoma cells have been observed in vitro and in vivo (26-28).

Multi-gene expression is one of the molecule characteristics of HCC occurring in development (29), antigen investigation and immunotherapy of $\mathrm{HCC}$ remain unsatisfactory, antigens and their coding genes of HCC are not distinct, so it is urgent to search for new antigens and identify their epitopes.

In this study, a cDNA expression library was constructed from the total RNA, which was extracted from welldifferentiated HCC tissue. SEREX was applied to screen the 
Table I. Sequences of primers for polymerase chain reaction amplification.

\begin{tabular}{|c|c|c|c|}
\hline Clone no. & & Primer & Product size $\left(b^{a}\right)$ \\
\hline 1 & $\begin{array}{l}\text { Forward } \\
\text { Reverse }\end{array}$ & $\begin{array}{l}\text { 5'-AAGGACCCTATCGTCAATG-3', } \\
\text { 5'-GGTAGCCCATCTGCTTGT-3' }\end{array}$ & 268 \\
\hline 7 & $\begin{array}{l}\text { Forward } \\
\text { Reverse }\end{array}$ & $\begin{array}{l}\text { 5'-TGTGCCTGTATGGAGTGG-3', } \\
\text { 5'-TTATTCCGTAAAGACCCT-3' }\end{array}$ & 260 \\
\hline 9 & $\begin{array}{l}\text { Forward } \\
\text { Reverse }\end{array}$ & $\begin{array}{l}\text { 5'-TTCGCCCTTGCTTGTAAT-3', } \\
\text { 5'-CCTGCCTCATGTCTCCCT-3' }\end{array}$ & 196 \\
\hline 11 & $\begin{array}{l}\text { Forward } \\
\text { Reverse }\end{array}$ & $\begin{array}{l}\text { 5'-AGGGTGAAGCATGGTGGC-3', } \\
\text { 5'-TGGAGTTTGGCAGGATGATAG-3' }\end{array}$ & 388 \\
\hline
\end{tabular}

${ }^{\mathrm{a} B a s e}$ pairs.

library with the mixed autologous and allogenic serum of HCC patients. The identified antigens may be used as new markers for the diagnosis and prognosis of HCC.

\section{Materials and methods}

Tissues and serum samples. This study was approved by the Ethics Review Committee of the First Affiliated Hospital, School of Medicine, Zhejiang University. A well differentiated HCC surgical resection sample from a man aged 57 years who had hepatitis B virus-related hepatitis, was used for the construction of the cDNA library. The patient had no history of other malignancies, autoimmune diseases, chronic alcoholic liver disease or hyper- $\gamma$-globulinemia due to chronic liver injury that may have caused a nonspecific immune response. To examine gene expression of the clones obtained by SEREX analysis, 20 surgically resected HCC specimens and 10 other cancer specimens, and corresponding samples from uninvolved regions were stored at $-80^{\circ} \mathrm{C}$. All these tissue samples were comfirmed by pathology.

Serum from 15 healthy volunteers, 22 patients with HCC, 20 patients with liver cirrhosis (LC), 20 patients with chronic hepatitis $(\mathrm{CH}), 8$ patients with gastric carcinoma (GC) and 5 patients with pancreatic carcinoma (PC) were used for analysis of the antibodies. The serum AFP level in patients with HCC was measured by enzyme-linked immunosorbent assay and cut-off value was set at $20 \mathrm{ng} / \mathrm{ml}$.

RNA extraction and construction of the cDNA library. Total RNA were extracted using TRIzol (Invitrogen Company) method and Poly A(+) RNA was obtained by an mRNA Purification kit (Sangon Company, Shanghai, P.R. China). The cDNA library was constructed in a $\lambda$ TriplEx 2 express vector using a SMART ${ }^{\mathrm{TM}}$ cDNA cloning kit (Clontech Company). The cDNA fragments were packaged into a $\lambda$ TriplEx 2 express vector and then transfected into $E$. coli, which resulted in $1.37 \times 10^{6}$ primary recombinants.

Immunoscreening and sequencing. Immunoscreening for the detection of reactive clones was performed with autologous serum, as described elsewhere $(7,30,31)$ with some modification. E. coli transfected with recombinant $\lambda$ TripleX $_{2}$ phages were plated onto LB-agar plates and expression of recombinant proteins was induced with isopropyl $\beta$-Dthiogalactoside (IPTG, Promega Company) for $6 \mathrm{~h}$. The membranes were blocked with BSA and incubated with a 1:5000 dilution of the alkaline phosphatase-conjugated antibody specific for human IgG (Southern Biotechnology Associate Company) for $2 \mathrm{~h}$. Reactive clones were visualized by staining with BCIP/NBT (Roche Company) for $0.5 \mathrm{~h}$, the resulting blue dots were marked on the filter with a needle. These premarked membrane were extensively washed with TBS, and then incubated with diluted autologous and allogenic HCC patient serum (1:1000), which had been preabsorbed with transfected E. coli phage lysate (Stratagene Company). The filters were stained and processed for visualization in a manner identical with that described above. Only clones that appeared blue and unmarked from the needle in the prescreening were considered serum positive. These clones were subcloned three times to obtain monoclonality. Positive clones were subcloned into pTriplEx 2 phagemid vector (Clontech Company) and the nucleotide sequences of cDNA inserts were determined using a BigDye cycle terminator ready reaction kit and $\mathrm{ABI}$ Prism automated DNA sequencer (PE Applied Bio systems, Foster City, CA).

Allogeneic serum screening. Clones that reacted with the autologous serum were purified and then mixed with nonrecombinant phages as negative controls at a 1:2 ratio. This mixture was tested against preabsorbed sera of interest by using the immunoscreening assay described above. In this study, we tested 15 healthy controls, 22 patients with HCC, 20 patients with LC, 20 patients with $\mathrm{CH}, 8$ patients with GC and 5 patients with PC.

Reverse transcription-polymerase chain reaction analysis. The mRNA expression pattern of the selected cDNAs that reacted only with sera from patients with HCC was analyzed by reverse transcription-polymerase chain reaction (RT-PCR) analysis. Total RNA from HCC tissue samples and corresponding samples of uninvolved liver were isolated by TRIzol method, and cDNA was generated from $3 \mu \mathrm{g}$ of RNA by reverse transcriptase (Fermentas Company, Vilnius, Lithuania) with Oligo-dT (Gibco Company) as primers. The sequences of the PCR primers are indicated in Table I. PCR for 28 amplification cycles (at $95^{\circ} \mathrm{C}$ for $1 \mathrm{~min}$, at $55^{\circ} \mathrm{C}$ for 


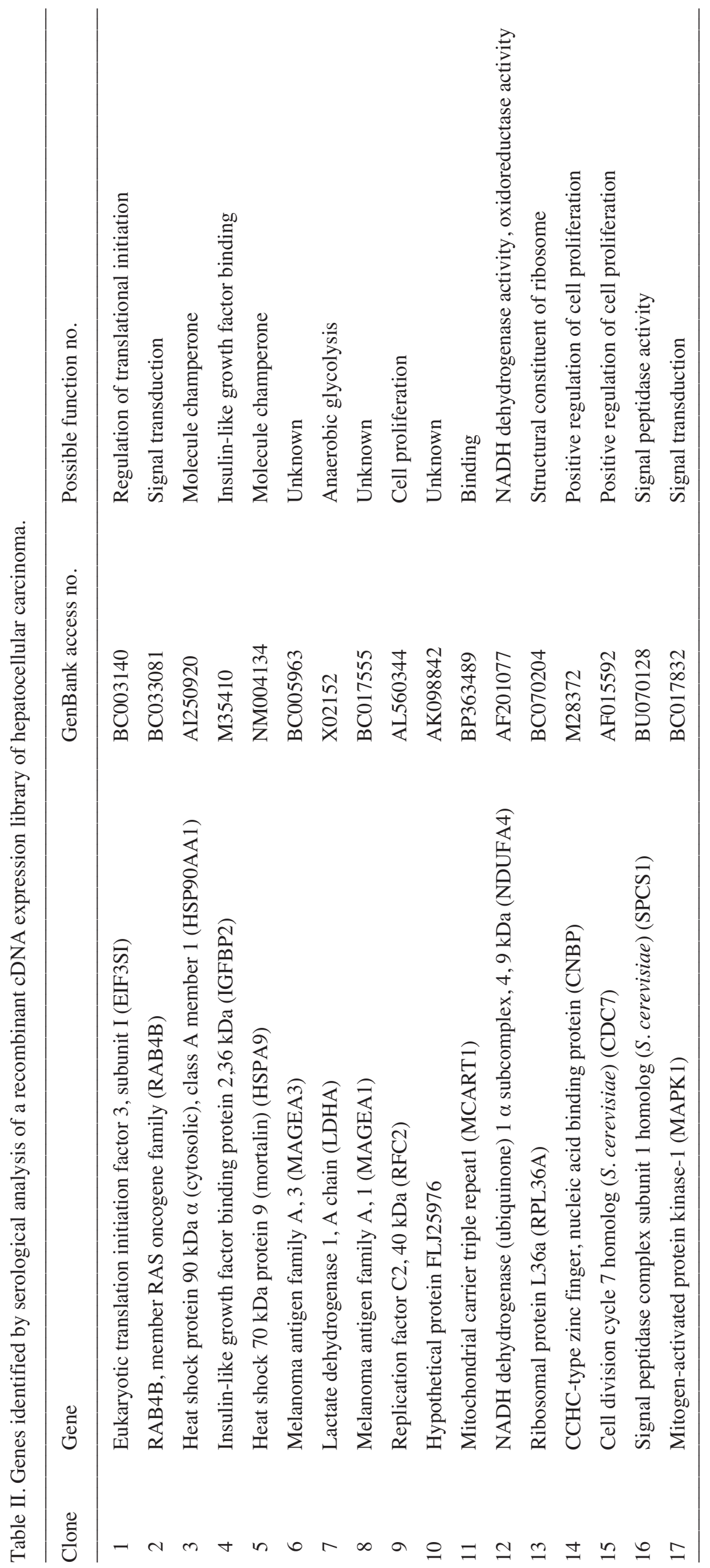


Table III. Genes reactivity of allogenic sera against the antigens identified by SEREX.

\begin{tabular}{|c|c|c|c|c|c|c|c|}
\hline Clone no. & Gene & $\begin{array}{l}\text { Health control } \\
\qquad(\mathrm{n}=15)\end{array}$ & $\begin{array}{l}\mathrm{HCC}^{\mathrm{a}} \\
(\mathrm{n}=22)\end{array}$ & $\begin{array}{c}\mathrm{LC}^{\mathrm{b}} \\
(\mathrm{n}=20)\end{array}$ & $\begin{array}{c}\mathrm{CH}^{\mathrm{c}} \\
(\mathrm{n}=20)\end{array}$ & $\begin{array}{l}\mathrm{GC}^{\mathrm{d}} \\
(\mathrm{n}=8)\end{array}$ & $\begin{array}{l}\mathrm{PC}^{\mathrm{e}} \\
(\mathrm{n}=5)\end{array}$ \\
\hline 1 & EIF3SI & 0 & $7(31.8 \%)$ & 0 & 0 & 0 & 0 \\
\hline 7 & LDHA & 0 & $10(45.5 \%)$ & 0 & 0 & 0 & 0 \\
\hline 9 & RFC2 & 0 & $6(27.3 \%)$ & 0 & 0 & 0 & 0 \\
\hline 11 & MCART1 & 0 & $11(50.0 \%)$ & 0 & 0 & 1 & 0 \\
\hline 5 & HSPA9 & 0 & 5 & 0 & 1 & 5 & 2 \\
\hline 6 & MAGEA3 & 0 & 12 & 2 & 1 & 6 & 4 \\
\hline 8 & MAGEA1 & 0 & 13 & 1 & 1 & 7 & 5 \\
\hline 3 & HSP90AA1 & 0 & 9 & 1 & 0 & 6 & 3 \\
\hline 2 & RAB4B & 2 & 6 & - & - & - & - \\
\hline 4 & IGFBP2 & 1 & 4 & - & - & - & - \\
\hline \multirow[t]{2}{*}{10} & Hypothetical protein & & & & & & \\
\hline & FLJ25976 & 1 & 5 & - & - & - & - \\
\hline 12 & NDUFA4 & 3 & 7 & - & - & - & - \\
\hline 13 & RPL36A & 9 & 11 & - & - & - & - \\
\hline 14 & CNBP & 3 & 8 & - & - & - & - \\
\hline 15 & CDC7 & 1 & 2 & - & - & - & - \\
\hline 16 & SPCS1 & 0 & 1 & - & - & - & - \\
\hline 17 & MAPK1 & 0 & 1 & - & - & - & - \\
\hline
\end{tabular}

${ }^{\mathrm{a}}$ Hepatocellular carcinoma; ${ }^{\mathrm{b}}$ liver cirrhosis; ${ }^{\mathrm{c}}$ chronic hepatitis; ${ }^{\mathrm{d}}$ gastric carcinoma and ${ }^{\mathrm{e}}$ pancreatic carcinoma.

$1 \mathrm{~min}$ and at $72^{\circ} \mathrm{C}$ for $1 \mathrm{~min}$ ) was carried out on each cDNA sample. Furthermore, mRNA expression of the selected clones in cancer specimens and corresponding uninvolved regions were analyzed by RT-PCR described as above, including tissues of the stomach, colon, pancreas, kidney, bladder, prostate, uterus, testicle, brain and lung.

\section{Results}

Thirty-eight positive clones were obtained by immunoscreening of the primary cDNA expression library with autologous sera, representing 17 different cDNA sequences, from 324 to $805 \mathrm{bp}$, which coded for known or closely related proteins (Table II).

Among the 17 antigens identified, 14 cDNAs were genes with known functions, the other 3 cDNAs were genes with unknown functions, including hypothetical protein FLJ25976, MAGEA3 and MAGEA1.

Antigens of EIF3I (clone 1), LDH-A (clone 7), RFC2 (clone 9) and MCART1 (clone 11) reacted only with sera from patients with HCC (Table III). Their response frequency was $31.8,45.5,27.3$ and $50.0 \%$, respectively. Antigens of HSPA9 (clone 5), MAGEA3 (clone 6), MAGEA1 (clone 8) and HSPCA (clone 3) reacted with sera from patients with HCC and not with control sera, however, they also reacted with sera from patients with $\mathrm{LC}, \mathrm{CH}, \mathrm{GC}$ and PC. The other 9 antigens (clone $2,4,10,12,13,14,15,16,17)$ reacted with sera from both health control samples and patient samples.

The expression of HCC-specific antibodies against EIF3SI, LDHA, RFC2 and MCART1 antigens was compared with clinical parameters in 22 HCC samples (Table IV). Although 4 patients were negative for the 4 antibodies, $81.8 \%$ of patients with $\mathrm{HCC}$ reacted with at least 1 of 4 antigens and serological responses were induced even in patients with HCC tumors that measured $<2 \mathrm{~cm}$ in greatest dimensions. The presence of the antibodies did not correlate with patient age, gender, tumor size, the grade of differentiation, serum AFP level, HBV infection, or the combination of liver cirrhosis ( $>00.05)$.

Although the 4 antigens were immunogenic only in patients with $\mathrm{HCC}$, mRNAs from the 4 antigens were expressed constitutively in all HCC samples and their corresponding, uninvolved liver samples by RT-PCR analyses. They nearly expressed in all the human cancer tissues and corresponding uninvolved regions.

\section{Discussion}

In the current study, we applied the SEREX technique to identify tumor antigens in human HCC and found that antibodies against EIF3SI, LDHA, RFC2 and MCART1 were produced specifically in patients with HCC, while the expression of these antigens was not disease-specific. 
Table IV. Clinical parameters of patients with HCC and antibody production against EIF3SI, LDHA, RFC2 and MCART1.

\begin{tabular}{|c|c|c|c|c|c|c|c|c|c|c|}
\hline Patient & Age & Gender & $\begin{array}{l}\text { Tumor size } \\
(\mathrm{cm})\end{array}$ & $\begin{array}{c}\text { AFP } \\
(\mathrm{ng} / \mathrm{ml})\end{array}$ & Differentiation & Virus & EIF3SI & LDHA & RFC2 & MCART1 \\
\hline 1 & 52 & $\mathrm{M}$ & 5.4 & 193 & well & $\mathrm{HBV}$ & + & + & & + \\
\hline 2 & 11 & $\mathrm{M}$ & 1.9 & 1275 & $\bmod$ & Negative & + & & & + \\
\hline 3 & 49 & $\mathrm{M}$ & 4.0 & 11.2 & well & Negative & & + & & + \\
\hline 4 & 61 & $\mathrm{M}$ & 6.5 & 2.4 & $\bmod$ & Negative & & & + & + \\
\hline 5 & 60 & $\mathrm{M}$ & 10.0 & 17.6 & well & HBV & + & + & + & \\
\hline 6 & 44 & $\mathrm{M}$ & 5.5 & 2339 & $\bmod$ & $\mathrm{HBV}$ & & + & + & \\
\hline 7 & 50 & M & 6.0 & 2498 & nd & $\mathrm{HBV}$ & + & + & & + \\
\hline 8 & 42 & $\mathrm{M}$ & 3.7 & 1210 & nd & $\mathrm{HBV}$ & & & + & + \\
\hline 9 & 38 & $\mathrm{M}$ & 3.0 & 1.0 & $\bmod$ & HBV & + & & & \\
\hline 10 & 69 & $\mathrm{~F}$ & 5.3 & 2.6 & well & Negative & & + & & \\
\hline 11 & 60 & M & 4.5 & 11.4 & well & HBV & & & & \\
\hline 12 & 57 & $\mathrm{M}$ & 8.6 & 250.4 & nd & $\mathrm{HBV}$ & + & & & + \\
\hline 13 & 51 & $\mathrm{M}$ & 11.8 & 63.4 & well & $\mathrm{HBV}$ & & + & & \\
\hline 14 & 49 & $\mathrm{M}$ & 6.5 & 1636 & nd & $\mathrm{HBV}$ & & & + & + \\
\hline 15 & 49 & $\mathrm{M}$ & 3.2 & 562 & $\bmod$ & HBV & + & + & + & \\
\hline 16 & 41 & $\mathrm{M}$ & 4.0 & 135.7 & well & HBV & & & & \\
\hline 17 & 41 & $\mathrm{~F}$ & 5.6 & 2.8 & well & Negative & & & & \\
\hline 18 & 56 & $\mathrm{M}$ & 5.0 & 2108 & nd & HBV & & + & + & \\
\hline 19 & 40 & $\mathrm{~F}$ & 2.6 & 102.9 & $\bmod$ & HBV & & & & \\
\hline 20 & 75 & $\mathrm{~F}$ & 3.7 & 2.5 & well & HBV & & + & & + \\
\hline 21 & 44 & $\mathrm{M}$ & 5.5 & 1017.5 & $\bmod$ & Negative & & & & + \\
\hline 22 & 57 & $\mathrm{M}$ & 8.6 & 2381 & $\bmod$ & HBV & & & & + \\
\hline
\end{tabular}

eIF3SI is the p36 subunit of eukaryotic translation initiation factor protein complex, which has translation initiation factor activity during the course of protein synthesis. Overexpression of EIF3SI has been reported in HCC (32) and nasopharyngeal carcinoma $(33,34)$.

Other subunits from the same family with EIF3SI, such as EIF3S10 $(35,36)$ and EIF2 (37) have been reported in various kinds of cancers, including squamous cell esophagus carcinoma, lung cancer, melanoma, prostate cancer and ovarian cancer.

LDHA is a subunit of $\mathrm{LDH}$, which converts pyruvate lactate under anaerobic conditions in normal cells. LDHA was recognized by breast cancer patient sera (38) and was reported overexpressed in prostatic carcinoma (39) and renal cell carcinoma (40). Reduction in LDHA activity resulted in diminished tumorigenicity, which was reversed by complementation with the human ortholog LDHA protein, this demonstrates that LDHA plays a key role in tumor maintenance (41).

RFC2, a subunit of RFC, is a DNA binding protein and ATPase that acts as a clamp loader of the proliferating cell nuclear antigen (PCNA) processivity factor for DNA polymerases $\delta$ and $\varepsilon$. RFC2 has been reported in glioblastomas
$(42,43)$, hydatidiform moles, invasive moles and choriocarcinomas (44).

MCART1 codes for a protein whose function is unknown, possibly it participates in enery metabolism during tumorigenicity.

The frequency of anti-EIF3SI, anti-LDHA, anti-RFC2 and anti-MCART1 was high, among the eight patients who were negative for AFP, two patients had antibodies against EIF3SI, four patients against LDHA, two patients against RFC2 and three patients against MCART1. In addition, antibodies against EIF3SI and MCART1 were found even in patients with small HCC tumors, suggesting that they may be useful as a complementary marker for the diagnosis of HCC.

Antigens identified by SEREX represents extremely diverse proteins, most of which result from overexpression in HCC cells. It is not possible to draw conclusions on how these antigens could be involved in tumorigenesis, while rapid turnover of HCC cells may increase the chance of antigen presentation and result in antibody production against these antigens with HCC. The corresponding vaccine injection is a promising therapy in patients with HCC. 


\section{Acknowledgements}

Xiaohong Chen and Huanyong Chen were recipients of a grant from Natural Science Foundation of Heilongjiang, P.R. China (D200626). We thank Dr Hangping Yao and Xiaoping Pan (Key Laboratory of Health Ministry, Institute of Infectious Diseases, The First Affiliated Hospital, School of Medicine, Zhejiang University, Hangzhou, P.R. China) for technical assistance and Hongjuan Zhou, Qi Xia, Jingjing Jiao (Key Laboratory of Health Ministry, Institute of Infectious Diseases, The First Affiliated Hospital, School of Medicine, Zhejiang University, Hangzhou, P.R. China) for substantial help in the experiments.

\section{References}

1. Okuda K: Hepatocellular carcinoma: recent progress. Hepatology 15: 948-963, 1992.

2. Tang ZY: Hepatocellular carcinoma-cause, treatment and metastasis. World J Gastroenterol 7: 445-454, 2001.

3. Sahin U, Türeci O, Schmitt H, et al: Human neoplasms elicit multiple specific immune responses in the autologous host. Proc Natl Acad Sci USA 92: 11810-11813, 1995.

4. Van der Bruggen P, Traversari C, Chomez P, et al: A gene encoding an antigen recognized by cytolytic $\mathrm{T}$ lymphocytes on a human melanoma. Science 254: 1643-1647, 1991.

5. Chen YT, Güre AO, Tsang S, Stockert E, Jäger E and Knuth A: Identification of multiple cancer/testis antigen by allogenetic antibody screening of a melanoma cell line library. Proc Natl Acad Sci USA 95: 6919-6923, 1998.

6. Jäger D, Stockert E, Jäger E, et al: Serological cloning of a melanocyte rab guanosine 5 '-triphonsphate-binding protein and a chromosome condensation protein from a melanoma complementary DNA library. Cancer Res 60: 3584-3591, 2000.

7. Chen YT, Scanlan MJ, Sahin U, et al: A testicular antigen aberrantly expressed in human cancers detected by autologous antibody screening. Proc Natl Acad Sci USA 94: 1914-1918, 1997.

8. Nakashima K, Shimada H, Ochiai T, et al: Serological identification of TROP2 by recombinant cDNA expression cloning using sera of patients with esophageal squamous cell carcinoma. Int J Cancer 112: 1029-1035, 2004

9. Kuboshima M, Shimada H, Liu TL, et al: Identification of a novel SEREX antigen, SLC2A1/GLUT1, in esophageal squamous cell carcinoma. Int J Oncol 28: 463-468, 2006.

10. Miles AK, Rogers A, Li G, et al: Identification of a novel prostate cancer-associated tumor antigen. Prostate 67: 274-287, 2007.

11. Wang RF, Johnston SL, Zeng G, Topalian SL, Schwartzentruber DJ and Rosenberg SA: A breast and melanoma-shared tumor antigen: $T$ cell responses to antigenic peptides translated from different open reading frames. J Immunol 161: 3598-3606, 1998

12. Jäger E, Gnjatic S, Nagata Y, Stockert E, Jäger D and Karbach J: Induction of primary NY-ESO-1 immunity: $\mathrm{CD} 8^{+} \mathrm{T}$ lymphocyte and antibody responses in peptide-vaccinated patients with NY-ESO-1+ cancers. Proc Natl Acad Sci USA 97: 12198-12203, 2000.

13. Wang W, Epler J, Salazar LG and Riddell SR: Recognition of breast cancer cells by $\mathrm{CD} 8^{+}$cytotoxic T-cell clones specific for NY-BR-1. Cancer Res 66: 6826-6833, 2006.

14. Valmori D, Souleimanian NE, Tosello V, et al: Vaccination with NY-ESO- 1 protein and $\mathrm{CpG}$ in Montanide induces intergrated antibody/Th1 responses and $\mathrm{CD} 8^{+} \mathrm{T}$ cells through cross-priming. Proc Natl Acad Sci USA 104: 8947-8952, 2007.

15. Odunsi K, Qian F, Matsuzaki J, et al: Vaccination with an NYESO-1 peptide of HLA class I/II specifictities induces integrated humoral and T cell responses in ovarian cancer. Proc Natl Acad Sci USA 104: 12837-12842, 2007.

16. Karbach J, Gnjatic S, Pauligk C, et al: Tumor-reactive CD8 ${ }^{+}$ T-cell clones in patients after NY-ESO-1 peptide vaccination. Int J Cancer 121: 2042-2048, 2007.

17. Thurner B, Haendle L, Röder C, et al: Vaccination with mage-3A1 peptide-pulsed mature, monocyte-derived dendritic cells expands specific cytotoxic $\mathrm{T}$ cells and induces regression of some metastases in advanced stage IV melanoma. J Exp Med 190: 1669-1678, 1999
18. Marchand M, van Baren N, Whynants P, et al: Tumor regression observed in patients with metastatic melanoma treated with an antigenic peptided encoded by gene MAGE-3 and presented by HLA-A1. Int J Cancer 80: 219-230, 1999.

19. van Baren N, Bonnet MC, Dréno B, et al: Tumoral and immunologic response after vaccination of melanoma patients with an ALVAC virus encoding MAGE antigens recognized by T cells. J Clin Oncol 23: 9008-9021, 2005.

20. Seil I, Frei C, Sültmann H, Knauer SK, Engels K and Jäger E: The differentiation antigen NY-BR-1 is a potential target for antibody-based therapies in breast cancer. Int J Cancer 120: 2635-2642, 2007.

21. Theurillat JP, Zürrer-Härdi U, Varga Z, et al: NY-BR-1 protein expression in breast carcinoma: a mammary gland differentiation antigen as target for cancer immunotherapy. Cancer Immunol Immunother 56: 1723-1731, 2007.

22. Stenner-Liewen F, Luo G, Sahin U, et al: Definition of tumorassociated antigens in hepatocellular carcinoma. Cancer Epedemiol Biomarkers Prev 9: 285-290, 2000.

23. Wang Y, Han KJ, Pang XW, et al: Large scale identification of human hepatocellular carcinoma-associated antigens by autoantibodies. J Immunol 169: 1102-1109, 2002.

24. Uemura M, Nouso K, Kobayashi Y, et al: Identification of the antigens predominantly reacted with serum from patients with hepatocellular carcinoma. Cancer 97: 2474-2479, 2003.

25. Zhong X, Ran YL, Lou JN, et al: Construction of human liver cancer vascular endothelium cDNA expression library and screening of the endothelium-associated antigen genes. World $\mathbf{J}$ Gastroenterol 10: 1402-1408, 2004.

26. Chan RC, Pang XW, Wang YD, Chen WF and Xie Y: Tansduction of dentritic cells with recombinant adenovirus encoding HCA661 activates autologous cytotoxic T lymphocytes to target hepatoma cells. Br J Cancer 90: 1636-1643, 2004.

27. Cao DY, Yang JY, Dou KF, Ma LY and Teng ZH: alphafetoprotein and interleukin-18 gene-modified dendritic cells effectively stimulate specific type-1 CD4- and CD8-mediated $\mathrm{T}$-cell responses from hepatocellular carcinoma patients in vitro. Hum Immunol 68: 334-341, 2007.

28. Butterfield LH, Ribas A and Meng WS: T-cell responses to HLA-A*0201 immunodominant peptides derived from alphafetoprotein in patients with hepatocellular cancer. Clin Cancer Res 9: 5902-5908, 2003.

29. Aznavoorian S, Murphy AN, Stetler-Stevenson WG and Liotta LA: Molecular aspects of tumor cell invasion and matastasis. Cancer 71: 1368-1383, 1993.

30. Scanlan MJ, Chen YT, Williamson B, et al: Characterizaion of human colon cancer antigens recongnized by autologous antibodies. Int J Cancer 76: 652-658, 1998.

31. Türeci O, Schmitt N, Fadle N, Pfreundschuh M and Sahin U: Molecular definition of a novel human galectin which is immunogenic in patients with Hodgkin's disease. J Biol Chem 272: 6416-6422, 1997.

32. Huang JS, Chao CC, Su TL, et al: Diverse cellular transformation capability of overexpressed genes in human hepatocellular carcinoma. Biochem Biophy Res Commun 315: 950-958, 2004.

33. Bin L, Hu C and Zhan F: The expression in situ of transforming growth factor beta $\mathrm{s}$, their receptors and TGF beta-receptor interacting protein-1 in nasopharyngeal carcinoma. Zhonghua Er Bi Yan Hou Ke Za Zhi 34: 210-212, 1999.

34. Bernardini S, Melino G, Saura F, Annicchiarico-Petruzzelli M, Motti C, Cortese C and Federici G: Expression of co-factors (SMRT and Trip-1) for retinoic acid receptors in human neuroectodermal cell lines. Biochem Biophys Res Commun 234: 278-282, 1997.

35. Chen G and Burger MM: p150 overexpression in gastric carcinoma: the association with $\mathrm{p} 53$, apoptosis and cell proliferation. Int J Cancer 112: 393-398, 2004.

36. Chen G and Burger MM: p150 overexpression and its prognostic value in squamous-cell carcinoma of the esophagus. Int J Cancer 84: 95-100, 1999.

37. Rosenwald IB, Wang S, Savas L, Woda B and Pullman J: Expression of translation initiation factor eIF-2alpha is increased in benign and malignant melanocytic and colonic epithelial neoplasms. Cancer 98: 1080-1088, 2003.

38. Forti S, Scanlan MJ, Invernizzi A, et al: Identification of breast cancer-restricted antigens by antibody screening of SKBR3 cDNA library using a preselected patient's serum. Breast Cancer Res Treat 73: 245-256, 2002. 
39. Sharief FS, Mohler JL, Sharief Y and Li SS: Expression of human prostatic acid phosphatase and prostate specific antigen genes in neoplastic and benigh tissues. Biochem Mol Biol Int 33: 567-574, 1994.

40. Vilà MR, Nicolás A, Morote J, de I and Meseguer A: Increased glyceraldehydes-3-phosphate dehydrogenase expression in renal cell carcinoma identified by RNA-based, arbitrarily primed polymerase chain reaction. Cancer 89: 152-164, 2000.

41. Fantin VR, St-Pierre J and Leder P: Attenuation of LDH-A expression uncovers a link between glycolysis, mitochondrial physiology, and tumor maintenance. Cancer Cell 9: 425-434, 2006.
42. Nakahara Y, Shiraishi T, Okamoto H, Mineta T, Oishi T, Sasaki K and Tabuchi K: Detrended fluctuation analysis of genome-wide copy number profiles of glioblastomas using array-based comparative genomic hybridization. J Neurooncol 6: 281-289, 2004.

43. Suzuki T, Maruno M, Wada K, et al: Genetic analysis of human glioblastomas using a genomic microarray system. Brain Tumor Pathol 21: 127-134, 2004.

44. Cui JQ, Shi YF and Zhou HJ: Expression of RFC2 and PCNA in different gestational trophoblastic diseases. Ai Zheng 23: 196-200, 2004. 